\title{
Tracks of Shame: "Pudore" in the Writings of Female Holocaust Survivors in Italy
}

\author{
Giovanni Miglianti \\ University of Cambridge
}

\section{Abstract}

This paper analyses testimonial works by four female concentration camp survivors writing in Italian: Giuliana Tedeschi, Maria Arata, Elisa Springer, and Elvia Bergamasco. By focusing on the descriptions of their deportations and looking at their writings through the lens of the notion of pudore (a sense of awkwardness, modesty, or shame), this study examines gender-laden trauma within the historical context of the Holocaust as well as in the autobiographical responses of these women. The gendered reading of the selected texts follows three main threads of displacement, humiliation, and clothing, linking a sense of pudore to the excruciating indignities visited on the bodies and identities of these victims of genocide. The paper concentrates particularly on the liminal phase of the train journey towards and the entry into the camps, which is considered as prelude and 'initiation' to the Nazi assault on the victim's sense of gender identity.

Keywords: deportation, Holocaust, Italy, shame, women

\section{Introduction}

The poem 'Shemà, written in 1946, serves as an epigraph to Italy's most famous Holocaust memoir, whose title it contains in its central section:

Who toils in the mud

Who knows no peace

Who fights for half a loaf 
With no hair and no name

With no more strength to remember

With empty eyes and a womb as cold

As a frog in winter. (Levi 2015a: 1887)

In postwar Italy, particularly from the 1960s onwards, Primo Levi occupied the role of the Holocaust survivor-writer par excellence, while the new edition of his Se questo è un uomo [If This Is a Man], published by Einaudi in 1958, enjoyed national popularity and commercial success. ${ }^{1}$ Apart from introducing and stimulating reflection on one of the central preoccupations of the book, namely the (in)human condition of people in Auschwitz, 'Shemà' presents a clear division between the male and the female prisoner. Lines 5 to 14 follow normative gender expectations in describing a man's struggle in concentration camps by means of agency, with four active verb forms in lines 6 to 9 . The portrait of a woman prisoner, by contrast, conveys an appeal to corporeality and deprivation: she is somebody 'with no hair and no name, ' [w] ith no more strength', with 'empty eyes' and cold womb (1l. 11-13).

While referring to socially shaped conventions as well as to binary codes of masculine activity and feminine passivity that were part of the larger cultural script of the time, Levi's poem reveals, particularly in the description of the female inmate, some of the key aspects of the Nazi assault on the prisoners' sense of the private sphere. ${ }^{2}$ These aspects included the forced transformation of the body through shaving and hard labour, the substitution of names with serial numbers, and the dissolution of memory and of vital functions, as happens to hibernating frogs in the winter. Furthermore, one of the key motifs adumbrated in the poem in relation to women is an implicit form of shame or pudore. This particular emotion recurs often in the testimonies of female survivors and will form the central focus of this paper. ${ }^{3}$

Between September 1943 and April 1945, deportation from Italy of so-called 'racial' and 'political' prisoners meant forced transfer for more than 40,000 people, including about 7,100 women. ${ }^{4}$ My purpose in this paper is to discuss female survivors' experiences as conveyed in firsthand accounts of their deportation from Italy and their entrance to Nazi concentration camps in Germany and Poland. The paper comparatively analyses a selected corpus of memoirs written in Italian: Giuliana Tedeschi's Questo povero corpo ('This Poor Body', or. ed. 1946), Maria Arata's Il ponte dei corvi ('The Crows' Bridge', 1979), Elisa Springer's Il silenzio dei vivi ('The Silence of the Living', 1997), and Elvia Bergamasco's Il cielo di cenere ('Ashes in the Sky', 2005). Tedeschi and Springer were imprisoned in Auschwitz as they were Jewish, while Arata and Bergamasco were deported as political prisoners to Ravensbrück and Auschwitz, respectively; they all wrote in Italian (despite Springer being Viennese born of an Hungarian family), and none of their memoirs has been translated into English. 
In these, as in many other Holocaust writings, the camp - the Lager functions as a narrative fulcrum; yet an analysis of the initial moments of the concentrationary experience can provide important insights into the systematic dehumanization to which the outward voyage constituted a prelude, and the entry into the Lager a sort of 'initiation' (as Springer puts it in ES 73, echoing the title of a chapter of Se questo è un uomo). The concept of pudore will prove useful in addressing the question of the gender implications of trauma, or 'gender-based wounding' (Horowitz, 1998: 366), in women's Holocaust narratives. In fact, it will prove particularly relevant in the analysis of the liminal moments that constitute a sort of twofold prologue, marking both the start of the journey down into the concentration camp and the beginning of its later narration.

\section{Tracking Pudore}

While it would be absurd to establish hierarchies between the victimization of men and that of women in the univers concentrationnaire, the consideration of gender-specific trauma can prove important for a deeper reading of Holocaust memoirs - one that I aim at in undertaking this paper. Potential experiences peculiar to women in concentration camps include the cessation of menses, pregnancy, abortion, childbirth, killing of newborn babies; Jewish women in particular were deported as Jewish and as women, due to their ability to perpetuate the 'race' (Rigelheim, 1998: 348).

Despite critical stereotypes of an already established knowledge of women's suffering in the Lager (Mengaldo, 2007: 46-47) and of the risk that 'discussions of sexuality [may] desecrate the memory of the dead or the living or the Holocaust itself' (Ringelheim, 1998: 345), scholars have recently queried the implicit normativity of male testimonies and further investigated female survivors' accounts, including those written in Italian. ${ }^{6}$ This paper aims to follow a similar path, without erasing undeniable differences among female prisoners, yet concentrating on the insight offered by a gendered reading of female memoires through the lens of pudore.

A term that translates with difficulty into English, pudore derives from Latin pudor, the modesty allegedly characteristic of women. ${ }^{7}$ It shares its etymology with the euphemistic pudenda (literally, 'the shameful parts'), an equivocation interestingly used in English to refer only to the female genitals, intended 'in their lack by comparison with those of the men' (Brennan 2002: 52). ${ }^{8}$ As a culturally coded affect, pudore refers to commonly shared norms of reserve or awkwardness in a specific society and covers most relationships of an individual with others, involving concepts of physical concealment (through gestures, behaviour, and clothing), and shamefulness of one's body, as well as visibility (understanding sight as a social fact). For the purpose of this essay, pudore is understood as the sense of modesty, self-protection, or shame, broadly pertaining to an individual's exposure and in a socially charged situation, with special reference to the sphere of intimacy and sexuality. As a gendered concept, pudore raises questions of exposure and disclosure, as well as of relative degrees of showing and not showing, revealing and concealing, telling or not telling.

In discussing pudore as a central category for understanding the gender implications of deportation in the selected corpus of writings, I focus on 
three main threads: 1) displacement in the journey towards the concentration camp; 2) bodily humiliation at the arrival in the Lager; 3) dress as an external symbol of the deportees' intimate sense of their human nature. I consider these three aspects, composing a tragic path of 'initiation', as part of a deliberate plan of physical and moral assault on the women deportees - one leading to what, with reference to Giuliana Tedeschi's definition (pertaining to both the literal stripping and the moral plunder), has been called a 'spoliazione dell'individualità femminile' ['despoliation of female individuality'] (Bravo and Jalla, 1987: 206).

\section{Displacement}

In defining pudore as linked to awkwardness, rather than to its cognates embarrassment or discomfort (the relevance of both notwithstanding), I suggest the possibility of a narratological approach to the testimonies, one not solely characterized by sexual and moral implications, but also informed by an understanding of testimonies as written texts, in which the survivors express their experiences through language. According to the Oxford English Dictionary, 'awkward' stems etymologically from 'in an awk [that is to say, wrong] direction'; in general, Holocaust writings themselves include the idea of a life trajectory that has been blocked and subverted. The capture, the literal and metaphorical arrest, marks the very beginning of Maria Arata's memoir: 'On July 4, 1944 I was arrested in my house at 44 via Garofalo' (MA 17). ${ }^{9}$

Following this critical moment and, often, a period of detention, in prison as well as internment camps, the deportation from Italy across the railroads of Europe has a double significance in many survivors' memories. On the one hand, the voyage constitutes a threshold, prefiguring the Lager and the violence that will dominate it; on the other, the train symbolises the passage from the familiar context forcefully left behind and the new, incomparable horizon that begins to be revealed (cf. Greppi, 2012: 27-29). Aside from the occasional gesture of sympathy that the deportees received within the national borders from some members of the civil population (mainly local women and railway men), their journey, which for many had no return, indicates an eradication process characterized primarily by physical experiences of suffering and humiliation. ${ }^{10}$ The Nazis' policy of packing prisoners inside the carriages of freight or cattle cars showed the manifest intent of an abrupt dehumanization, while inflicting the first collective violation on the deportees' sense of pudore. Survivors often recall how they were reduced to bestial conditions already during the outward voyage:

we were exhausted, hungry, thirsty, desperate. [...] In the car the smell was vile: urine and feces of motionless people were mixed with the straw.

[...] We were frightened beasts and trembled at any suspicious noise. The first act of depersonalisation, the first manifestation of the decay of our human condition was tragically beginning! (ES 63) ${ }^{11}$

In addition to hunger and thirst, excessive heat or cold, extremely poor hygiene conditions and the nauseating smell described by Springer; the 
overcrowding impeded movement and prevented resting, while the forced sharing of such restrictive space raised questions of necessary body contact (MA 21) and the difficult arrangement of the many pieces of luggage (ibid., and EB 70).

Three memoirists of our corpus touch upon the deportation and they all refer to luggage: problematic due to the crowded conditions in the trucks, the suitcases had often been carefully prepared (with selected clothes, EB 65 , or with presents from friends, MA 21) and represented the last material memory of home - yet they were confiscated upon arrival. In Auschwitz as in Ravensbrück, the prisoners were invited to leave their luggage behind and falsely told that it would later be returned to them (ES 65).

The entrance to the Lager coincided with the abandon of what Jorge Semprún (1999: 279) calls the 'monde des vivants' ['world of the living'], together with its material symbols and moral code. For women deportees, that ordinary world was generally one where home life provided concealment and privacy (Wanrooij, 1990: 97-131). The Fascist regime enforced supposedly biological roles of women as caretakers by legally allotting them 'a subordinate position in the family' within the domestic space (Willson, 2010:7) and excluding them 'from the formal political system' (De Grazia, 1992: 6). Nevertheless, at least for two of the women survivors of our corpus home is mainly the setting of a positive, nostalgic memory, so that Bergamasco's autobiographical account begins with a description of her family (and homely) life in rural Friuli, while Springer's opens with a description of her infancy in a well-off Viennese household. For both, losing their luggage upon arrival at the foreign camp meant losing that sense of domesticity and protection that they profoundly linked to their own feminine pudore. Bergamasco has a rather touching line to mark her attempt to resist such displacement: 'I let my long hair down and tied the red ribbon that had kept it together onto my suitcase' (EB 72). But very soon she would lose both her suitcase and her long hair.

\section{Humiliation}

A second motif of defeminisation is best summed up by the following quotation from Giuliana Tedeschi's memoir:

Violently deprived of our clothes, the last possession and memory of our home, we found ourselves naked in front of ourselves in the showers' place. It was as though somebody had simultaneously stripped away from us both the clothing and something of our spiritual being. The sense of pudore, the modesty, the reciprocal respect, and the conventions that were the result of our 'education' and social life, which were undeniably part of ourselves, were brutally subverted. (GT 13)

One of the first published testimonies on the concentrationary universe, Tedeschi's memoir begins in medias res and, from its very title, concentrates on female bodily humiliation in the camp. The initial lines present the result of the uprooting process previously described: after leaving their suitcases behind, the prisoners were also deprived of their clothes, and together 
with them of part of their 'spiritual being' ['bagaglio spirituale'], which in the original Italian text sounds more like 'spiritual luggage.' The author directly evokes the notion of pudore to describe the brutal subversion (another awk turn) of basic social norms to which she had been educated.

In fact, the experience of public and collective nudity had a traumatic impact especially on women deportees. While most men, thanks to military service, had probably become used to undressing in the presence of others, ${ }^{12}$ gender socialisation had imposed on girls and women of the time strong ideas of privacy. Thus, all the survivors of our corpus recount the forced exposure of the body as a violation of the profound pudore that all felt in connection to their sense of femininity. What Arata describes as 'the natural repugnance toward the often not too young, limp, and disfigured bodies' (MA 29 [emphasis added]) was perhaps not so 'natural', but rather a cultural shock produced by the social values and conventions that shaped these women's relationship with their own bodies as well as with those of others (cf. Coslovich 1997: 283-85).

With different style and language, both Tedeschi and Bergamasco, forty and fifty years later respectively, tried to explain such conventions to their readers by stressing the bodily shame felt by female inmates in front of the forced display of their nakedness:

At that time women cared more than nowadays about physical discretion, body care, even about the aesthetic details of their garments, and they could not reveal their nakedness without being traumatised. (Tedeschi, 1995: 13-14)

I do not know whether today's young girls will undress in front of their mother or whether today's women will walk naked in front of a sixteen or seventeen year old girl. Nowadays lots of progress has been made, studies, openings, in all fields, but the sense of pudore at that time was huge for us. (EB 74)

After a first 'selection' by Nazi 'doctors' based on rough criteria of age and ability to work (failure to meet these criteria resulted in immediate assassination), women's entry procedures in concentration camps generally included shaving of the head and of all body hair (as part of the disinfection process), vaginal examination to check for hidden valuables, and (only in Auschwitz) registration by means of an identification number tattooed on each prisoner's left forearm (Chiappano, 2014: 209). With reference to pubic hair removal, Springer recalls: 'In that very moment I lost all my dignity and my sense of pudore' (ES 71). These operations, often conducted by male prisoners, were overseen by armed SS camp guards, who verbally abused the newcomers and whose presence increased the physical humiliation of the women inmates.

Aside from sexual verbal humiliation, which Heinemann defines as ' $[t]$ he most universal form of sexual assault on women [...], especially immediately upon entrance to a concentration camp' (1986: 16), survivors describe beatings, or the threat of beatings, as a traumatic and recurrent element of the initiation process to life in the Lager. Not only male guards (ES 66), but also female SS are 
portrayed as wielding sticks and batons (ES 71), far from expressing any sort of gender solidarity.

\section{Clothing}

As mentioned before, pudore is strongly connected with questions of vision and visibility; iconographically, and throughout art history, it is often represented by acts of diverting the gaze (see GT 27 and 82) or covering one's eyes with one's hands. Sight also plays a critical role in the extreme case of the concentration camps. Upon arrival, the first impact with the reality of this new, 'incomprensibile' ['incomprehensible'] (Levi, 2007: 25) place happens for many through the vision of those prisoners already assimilated to the Lager system. Arata recalls looking for the first time at a group of female inmates carrying the naked dead bodies of fellow prisoners as 'the vision that makes us [newly arrived prisoners] well aware of the harsh reality' of Ravensbrück (MA 27); Tedeschi recounts how she and the people who arrived with her 'felt so alien to those women that our eyes had glimpsed with sadness and astonishment from outside the barbed wire' and how they 'were shocked when forced to see [...] what those rags were covering, the transformation suffered by the bodies of the older prisoners' (GT 16). After completing the 'initiation' process, looking at the camp's inhabitants once more assumes the significance of a prophecy: the other women, with fully shaved heads and faces from which - in Tedeschi's own written words - 'suffering had cancelled not only women's grace, but even any feminine quality' (ibid.), are now mirrors of oneself. ${ }^{13}$

Tedeschi's and her fellow prisoners' 'desire to cover our bodies again' had just been satisfied with a 'ritual of dressing' (GT 14), but the clothes received are a source of further humiliation. Once 'considered to be the original motives for putting on clothes' (Hollander, 1993: 83), notions of modesty and protection cannot be associated with the Lager uniform, constituted by tattered rags that prove unsuitable for the weather conditions of Poland and Germany (MA 29). Meanwhile, the lack of undergarments or sanitary napkins (ES 72; EB 77) caused major difficulties to the female prisoners before the onset of amenorrhea, originated by undernourishment and mental shock. Such nonfeminine clothing, often bearing classification symbols in the shape of colored triangles, marked the further reification of the deportees.

While pudore as an affect discourages the disclosure of a body part or an emotion, this is exactly what was experienced by female prisoners, for whom the 'new' clothes meant the real entrance as Stück (literally 'pieces') to the camp system. Far from being 'a necessary sign of full humanity' for Western people, according to Hollander's definition of being dressed (1993: 83), concentration camp uniforms functioned rather as means of depersonalization and assimilation to the Lager mechanism, while marking - according to Arata - 'the forced obliteration of our self, of everything in us that we can guard most closely and intimately' (MA 29).

After dedicating two paragraphs to the description of the uncomfortable clothes that she was forced to wear, Arata significantly concludes her chapter on the 'Entrance to the Lager' (MA 26-30) with the following words: 'Thus, undressed, we were headed towards a barrack' (in Italian: 'Così spogliate siamo avviate ad una baracca', MA 30, emphasis mine). Thus, spoliation, a term 
evocatively used also by Tedeschi (GT 25), is the ultimate motif and the best summary of the initial, critical phase of women's concentrationary experience.

\section{Conclusion}

Focusing on tropes of transition, body, and dress, this paper has shown how the physical and moral mortification experienced by these four women deportees was associated by them all, in their narratives, with the concept of pudore, whether they make direct reference to it (EB 68, ES 71, GT 13) or not (MA). From the moment of the (albeit forced) act of travelling on trains from their familiar world to the unknown univers concentrationnaire, female deportees break the image offered by Barthes (2002: 13-14) of sedentary women historically carrying on 'the discourse of absence, for which 'Man hunts, journeys; Woman is faithful (she waits)', in a similar fashion to what was presented in Levi's 'Shemà. Regardless of their gender, Holocaust victims experienced the violence of deportation on cattle cars, they faced bodily humiliation, and they were despoiled of their luggage, clothes, and pudore. Such a complex process of depersonalisation, intentionally aimed to reduce prisoners to their physicality so that their last mechanical energies could be exploited by the Nazi system (Coslovich, 1997: 283), was particularly traumatic for female prisoners.

My argument presents the Holocaust as an assault not only on humanity, but also on the victims' sense of gender identity. In the binary terms employed by the authors of the four memoirs that this paper has analysed, the concentration camp experience can be read both as an assault on the female prisoners' sense of femininity (in fact, none of them questions her own female identity, yet all feel that it was questioned by the Nazis), and also generally on identity (as framed by Horowitz, 1998: 376). Of course, how female survivors put themselves into discourse, from a narratological perspective, depended on a variety of factors, including their level of education and social condition.

Pudore itself, as noted above, involves choices of telling or not telling. In fact, writing was a sort of second journey for the former deportees, but one that could lead to renewed humiliation. The capacity of Giuliana Tedeschi, Maria Arata, Elisa Springer, and Elvia Bergamasco to recount their experiences of depersonalisation and defeminisation, together with the choice of testimony rather than silence, marks their eventual return from the camps while implying a partial waiver to their sense of pudore. As Primo Levi stated, 'to write is to strip oneself naked' (2015b: 2242); this is particularly relevant in the case of Holocaust writing. While further study would be needed to address the wider question of the linguistic techniques associated with pudore in Holocaust testimonies, this paper explored the beginning of the dramatic and awk experiences of four women deportees as it emerges from their memoirs. The analysis of this liminal moment, which marks both the start of the journey down into the concentration camp and the beginning of its later narration, proved to be crucial in the understanding of gender implications of the Lager universe.* 


\section{Endnotes}

1 Cf. Gordon, 2012: 65, and Usher, 2007: 172.

2 Although feminist criticism has shown how the distinction between the public and the private is arbitrary and ideological (see Gavison, 1992), the notion of a 'sense of the private sphere' seems applicable to the narratives of women's Holocaust experiences, since their authors rarely question normative ideas of privacy and intimacy in their memoirs.

3 Cf. Wilma Braida's testimony in Coslovich, 1997: 284, and Lucia

Franco Gazzolini's testimony in Pezzetti, 2009: 170. See also Levi, 2007: 89.

4 Cf. Coslovich, 1997: 72, and D’Amico, 2009: 34-35.

5 Further references to these primary sources are given as follows: GT = Tedeschi, 2005; MA = Massariello Arata, 1979; ES = Springer, 1997; EB = Bergamasco, 2005. All English translations from texts written by these authors (including Tedeschi, 1995) are mine; I wish to thank Amelia Papworth for her careful proofreading.

6 Most notably De Angelis, 2007; Lucamante, 2012; and Chiappano, 2014. 7 The adjective modestus was generally associated with men (cf. Harvey, 2013: 1). In Republican Rome, goddess Pudicitia provided the model of feminine sexual virtue, namely chastity.

8 The affect itself is not exclusive to women, and in Western tradition dates back to Adam and Eve's gesture of covering themselves after feeling shame for their nudity in Genesis, 3.7. In Italian, the word pudore appears in the Penal Code as connected to the notion of 'sexual honour' or public morality (Codice penale, 2.9 ch. 2, 'Delle offese al pudore e all'onore sessuale'), yet no definition is provided for any of these concepts, aside from the dependence on pudore of the notion of 'obscenity'(art. 529).

9 An incipit that echoes the one by Levi (2001: 11).

10 Cf. Greppi, 2012: 60-65.

11 Analogous comparisons with animals are found in MA 22, and Levi 2007: 89.

12 Cf. Levi, 2007: 90.

13 Cf. Gordon 2001: 39-41.

* An earlier version of this paper was written, in partial fulfilment of the requirements for my Masters degree at the University of Cambridge, under the supervision of Brad Epps and Robert Gordon. I wish to thank them deeply for their inspiring guidance and their suggestions on previous drafts of this essay. While revising my draft in light of the discussion that took place at the 'Bonds \& Boundaries' UCL conference on 18 June 2015, I also benefited from the generous advice of Millicent Marcus at Yale University, from the insightful comments of Lea Niccolai and Sandro-Angelo de Thomasis, and from conversations with Julia Pucci; my sincere gratitude goes to them all.

\section{Works Cited}

Barthes, Roland. A Lover's Discourse: Fragments. Trans. Richard Howard. London: Vintage, 2002. Print.

Bergamasco, Elvia. Il cielo di cenere. Portogruaro: nuova dimensione, 2005. Print.

Bravo, Anna and Daniele Jalla, eds. La vita offesa. Milano: Angeli, 1987. Print. 
Brennan, Teresa. Between Feminism and Psychoanalysis. London: Routledge, 2002. Print.

Chiappano, Alessandra. Le deportazioni femminili dall'Italia fra storia e memoria. Eds. Bruno Maida and Brunello Mantelli. Milano: Unicopli, 2014. Print.

Coslovich, Marco. I percorsi della sopravvivenza. Storia e memoria della deportazione dall'Adriatisches Küstenland'. Milano: Mursia, 1997. Print.

D’Amico, Giovanna. 'La deportazione politica delle donne italiane: un bilancio.' Essere donne nei Lager. Ed. Alessandra Chiappano. Firenze: Giuntina, 2009. 33-43. Print.

De Angelis, Giovanna. Le donne e la Shoah. Roma: Avagliano, 2007. Print.

De Grazia, Victoria. How Fascism Ruled Women: Italy, 1922-1945. Berkeley and Los Angeles: University of California Press, 1992. Print.

Gavison, Ruth. 1992. 'Feminism and the Public/Private Distinction.' Stanford Law Review. 45.1 (1992): 1-45. Print.

Gordon, Robert S. C. The Holocaust in Italian Culture, 1944-2010. Stanford: Stanford University Press, 2012. Print.

Greppi, Carlo. L’ultimo treno. Racconti del viaggio verso il lager. Roma: Donzelli, 2012. Print.

Harvey, Tamara. Figuring Modesty in Feminist Discourse Across the Americas, 1633-1700. Farnham: Ashgate, 2013. Print.

Heinemann, Marlene E. Gender and Destiny: Women Writers and the Holocaust. Westport: Greenwood, 1986. Print.

Hollander, Anne. Seeing Through Clothes. Berkeley and Los Angeles: University of California Press, 1993. Print.

Horowitz, Sara R. "Women in Holocaust Literature: Engendering Trauma Memory." Women in the Holocaust. Eds. Dalia Ofer and Lenore J. Weitzman. New Haven and London: Yale University Press, 1998. 364-377. Print.

Levi, Primo. Se questo è un uomo. La Tregua. Torino: Einaudi, 2001. Print.

--- I sommersi e i salvati. Torino: Einaudi, 2007. Print.

--- "Collected Poems." The Complete Works of Primo Levi. Ed. Ann Goldstein. Trans. Jonathan Galassi. New York: Liveright, 2015a. Print.

--- "Other People's Trades" The Complete Works of Primo Levi. Ed. Ann Goldstein. Trans. Antony Shugaar. New York: Liveright, 2015b. Print.

Lucamante, Stefania. Quella difficile identità. Ebraismo e rappresentazioni letterarie della Shoah. Roma: Iacobelli, 2012. Print.

Massariello Arata, Maria. Il ponte dei corvi. Diario di una deportata a Ravensbrück. Milano: Mursia, 1979. Print.

Mengaldo, Pier Vincenzo. La vendetta è il racconto. Testimonianze e riflessioni sulla Shoah. Torino: Bollati Boringhieri, 2007. Print.

Pezzetti, Marcello. Il libro della Shoah italiana. I racconti di chi è sopravvissuto. Torino: Einaudi, 2009. Print.

Rigelheim, Joan. 'The Split Between Gender and the Holocaust.' Women in the Holocaust. Eds. Dalia Ofer and Lenore J. Weitzman. New Haven and London: Yale University Press, 1998. 340-350. Print.

Semprún, Jorge. Le Grand Voyage. Paris: Gallimard, 1999. Print.

Springer, Elisa. Il silenzio dei vivi. Allombra di Auschwitz, un racconto di morte e resurrezione. Venezia: Marsilio, 1997. Print.

Tedeschi, Giuliana. Memoria di donne e bambini nei Lager nazisti. Torino: Zamorani, 1995. Print.

--- Questo povero corpo. Alessandria: Edizioni dell'Orso, 2005. Print. 
Usher, Jonathan. 'Primo Levi, the Canon and Italian Literature.' The Cambridge Companion to Primo Levi. Ed. Robert S. C. Gordon. Cambridge: Cambridge University Press, 2007. 171-188. Print.

Wanrooij, Bruno P. F. Storia del pudore. La questione sessuale in Italia, 18601940. Venezia: Marsilio, 1990. Print.

Willson, Perry. Women in Twentieth Century Italy. Basingstoke: Palgrave Macmillan, 2010. Print.

\section{Biography}

Giovanni Miglianti is PhD student in Italian Literature at Yale University. He holds a BA in Humanities from the University of Udine and an MPhil in European Literature and Culture from the University of Cambridge. His main research interests lie in Italian literature and cultural history of the 20th century, with a particular focus on Primo Levi, representations of the Holocaust, and the writings of Italian exiles in the United States. 